\title{
The optimal decision of insulation in cladding structures for energy efficient buildings
}

\author{
Eliza Gumerova ${ }^{1, *}$, Olga Gamayunova ${ }^{1}$ and Liubov Shilova ${ }^{2}$ \\ ${ }^{1}$ Peter the Great St. Petersburg Polytechnic University,29 Politechnicheskaya St., St. Petersburg, \\ 195251, Russia \\ ${ }^{2}$ Moscow State University of Civil Engineering, Yaroslavskoe shosse, 26, Moscow, 129337, Russia
}

\begin{abstract}
Execution of thermal insulation for enclosing structures of residential properties is a sophisticated part of the thermal protection. The choice of insulation materials for external walls is one of the main ways to increase the performance of heat insulation. This article contains thermotechnical calculations of two enclosing structures due to conditions of Saint-Petersburg. According to the results, the thickness of the insulating layer and a total wall thickness of the exterior walls composed of concrete, insulation and sand-cement rendering are smaller than the same characteristics of wall construction of hollow tile, insulation and sandcement rendering.
\end{abstract}

\section{Introduction}

The implementation of thermal insulation for enclosing structures of residential facilities is the major area of thermal protection. Firstly, insulation allows using fuel and energy resources efficiently because of the ability of the supporting structures to keep heat inside the house. The right choice of insulation increases the comfort of living in any period of time [1].

Contemporary design and advanced technology allow engineers to meet all the requirements of thermal insulation process ant to provide heat-saving efficiency.

There are the key methods of thermal protection of cladding structures: insulation of external walls, sandwich panels for exterior structures and internal insulation. The choice of insulation materials for external walls is an essential part of the design of the thermal protection [5-7].

The purpose of this article is to compare the most commonly used wall constructions with using of extruded foam polystyrene as insulation with the aid of thermo-technical calculations of outer walls [8-11].

The insulation layer in these constuctions is the material "PENOPLEX WALL". It is an eco-friendly, water-resistant heater with the highest ability for a heatshield. This material has the nominal size $1200 \times 600 x(20 ; 30 ; 40 ; 50 ; 60 ; 80 ; 100) \mathrm{mm}$.

These are the following tasks of the article:

- To make the thermo-technical calculations of two outer walls constructions;

* Corresponding author: eliza_gumerova@mail.ru 
- To carry out a comparative analysis of wall constructions;

- To conclude about the efficiency of cladding structures.

We made the thermo-technical calculations in accordance with the requirements of the following regulations $[12,13]$ :

- Building code 23-02-2003 "Thermal protection of buildings";

- Building code 23-01-99 "Construction climatology";

- Code of conduct 23-101-2004 "Design of thermal protection of buildings".

\section{Experimental section}

The data: residential building in Saint-Petersburg. Relative humidity $\varphi_{\text {int }}=55 \%$. Mean air temperature in the building: $\mathrm{t}_{\text {int }}=20^{\circ} \mathrm{C}$. The type of enclosing structure: external walls. The task is to determine the required thickness of the insulation layer.
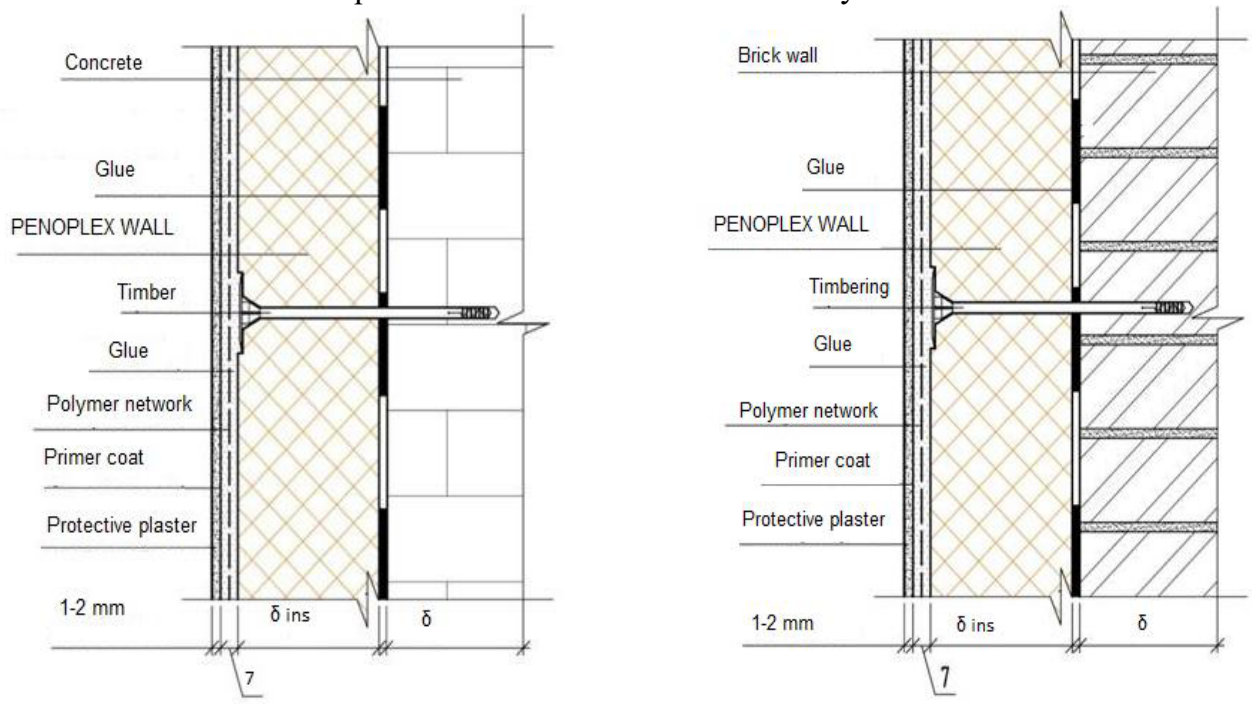

Fig. 1. The constructions of external walls no.1, 2 .

Table 1. The layers of construction no.1.

\begin{tabular}{|c|c|c|c|c|c|}
\hline $\begin{array}{c}\text { The } \\
\text { composition of } \\
\text { the walls from } \\
\text { the inside out }\end{array}$ & $\begin{array}{c}\text { The } \\
\text { thickness of } \\
\text { layer, } \delta, \mathrm{m}\end{array}$ & $\begin{array}{c}\text { Density } \\
, \rho_{0}, \\
\mathrm{~kg} / \mathrm{m}^{3}\end{array}$ & $\begin{array}{c}\text { Coefficient of heat } \\
\text { conductivity under } \\
\text { conditions A, } \\
\lambda_{\mathrm{A}}, \mathrm{W} / \mathrm{m}^{\circ}{ }^{\circ} \mathrm{C}\end{array}$ & $\begin{array}{c}\text { Coefficient of heat } \\
\text { conductivity under } \\
\text { conditions B, } \\
\lambda_{\mathrm{B}}, \mathrm{W} / \mathrm{m}^{\circ}{ }^{\circ} \mathrm{C}\end{array}$ & $\begin{array}{c}\text { Vapor } \\
\text { permeability } \\
\text { coefficient, } \\
\mu, \\
\mathrm{mg} /(\mathrm{m} \cdot \mathrm{h} \cdot \mathrm{Pa})\end{array}$ \\
\hline Concrete D400 & 0.3 & 400 & 0.14 & 0.15 & 0.23 \\
\hline $\begin{array}{c}\text { "PENOPLEX } \\
\text { WALL" }\end{array}$ & $?$ & 30 & 0.031 & 0.032 & 0.008 \\
\hline $\begin{array}{c}\text { Sand-cement } \\
\text { rendering }\end{array}$ & 0.007 & 1800 & 0.76 & 0.93 & 0.09 \\
\hline
\end{tabular}


Table 2. The layers of construction no.2.

\begin{tabular}{|c|c|c|c|c|c|}
\hline $\begin{array}{l}\text { The } \\
\text { composition of } \\
\text { the walls from } \\
\text { the inside out }\end{array}$ & $\begin{array}{c}\text { The } \\
\text { thickness } \\
\text { of layer, } \\
\delta, \mathrm{m}\end{array}$ & $\begin{array}{l}\text { Densit } \\
\mathrm{y}, \rho_{0}, \\
\mathrm{~kg} / \mathrm{m}^{3}\end{array}$ & $\begin{array}{c}\text { Coefficient of heat } \\
\text { conductivity under } \\
\text { conditions A, } \\
\lambda_{\mathrm{A}}, \mathrm{W} / \mathrm{m}^{.}{ }^{0} \mathrm{C}\end{array}$ & $\begin{array}{c}\text { Coefficient of heat } \\
\text { conductivity under } \\
\text { conditions B, } \\
\lambda_{\mathrm{B}}, \mathrm{W} / \mathrm{m} \cdot{ }^{0} \mathrm{C}\end{array}$ & $\begin{array}{c}\text { Vapor } \\
\text { permeability } \\
\text { coefficient, } \\
\mu, \mathrm{mg} /(\mathrm{m} \cdot \mathrm{h} \cdot \mathrm{Pa})\end{array}$ \\
\hline Hollow brick & 0.25 & 1200 & 0.47 & 0.52 & 0.17 \\
\hline $\begin{array}{l}\text { Sand-cement } \\
\text { rendering }\end{array}$ & 0.01 & 1800 & 0.76 & 0.93 & 0.09 \\
\hline Hollow brick & 0.12 & 1200 & 0.47 & 0.52 & 0.17 \\
\hline $\begin{array}{l}\text { "PENOPLEX } \\
\text { WALL" }\end{array}$ & ? & 30 & 0.031 & 0.032 & 0.008 \\
\hline $\begin{array}{l}\text { Sand-cement } \\
\text { rendering }\end{array}$ & 0.007 & 1800 & 0.76 & 0.93 & 0.09 \\
\hline
\end{tabular}

Humidity conditions during the cold period of the year depends on the relative humidity $\varphi_{\text {int }}=55 \%$ and the inside air temperature $\mathrm{t}_{\text {int }}=20{ }^{\circ} \mathrm{C}$. According to table $1[2]$, they are normal.

It is necessary to determine heat transmission resistance of cladding structure to calculate the required thickness of the insulating layer due to the requirements of sanitary code and energy efficiency [14].

1) Firstly, we should determine the required heat transmission resistance $R_{\text {req }}$ on the basis of sanitary-hygienic conditions according to the formula:

$$
R_{r e q}=n * \frac{t_{i n t}-t_{\text {ext }}}{\left(\Delta t_{n} * \alpha_{\text {int }}\right)}
$$

where $\mathrm{t}_{\text {int }}$ - the inside air temperature, ${ }^{\circ} \mathrm{C}, \mathrm{t}_{\text {int }}=20^{\circ} \mathrm{C}$;

$\mathrm{t}_{\mathrm{ext}}$ - the average outside air temperature, ${ }^{\circ} \mathrm{C}$, for Saint-Petersburg $\mathrm{t}_{\mathrm{ext}}=-26{ }^{\circ} \mathrm{C}[3]$;

$\mathrm{n}$ - coefficient which takes into account the dependence of the position of the enclosing structure to the outer air [2], $\mathrm{n}=1$;

$\alpha_{\text {int }}-$ coefficient of heat transfer of the internal surface of enclosing structures, $\mathrm{W} /\left(\mathrm{m} \cdot{ }^{\circ} \mathrm{C}\right)[2], \alpha_{\text {int }}=8.7 \mathrm{~W} /\left(\mathrm{m} \cdot{ }^{\circ} \mathrm{C}\right)$;

$\Delta \mathrm{t}_{\mathrm{n}}$ - temperature gradient, ${ }^{\circ} \mathrm{C}[2], \Delta \mathrm{t}_{\mathrm{n}}=4.0{ }^{\circ} \mathrm{C}$. Then

$$
\mathrm{R}_{\mathrm{req}}=1.32 \mathrm{~m}^{2 \circ} \mathrm{C} / \mathrm{W}
$$

2) Next step is to define required reduced total thermal resistance $R_{\text {req }}$ due to the conditions of energy efficiency [15-17]:

$$
R_{\text {req }}=a * D_{b}+b
$$

where a и $\mathrm{b}$ - coefficients; $a=0.00035 ; b=1.4$ [2].

Heating degree-day $\mathrm{D}_{\mathrm{b}},{ }^{0} \mathrm{C} \cdot$ days

$$
D_{b}=\left(t_{i n t}-t_{h t}\right) * z_{h t}
$$


where $t_{h t}-$ the average outside air temperature, ${ }^{\circ} \mathrm{C}$ [3]. For the season with the average daily temperature of outer air not above $8^{\circ} \mathrm{C} \mathrm{t}_{\mathrm{ht}}=-1.8^{\circ} \mathrm{C}$.

$\mathrm{Z}_{\mathrm{ht}}-$ the duration of the heating period, days [table 1,3]. For the season with the average daily temperature of outer air not above $8{ }^{\circ} \mathrm{C} \mathrm{z}_{\mathrm{ht}}=220$ days.

$$
\mathrm{D}_{\mathrm{b}}=4796^{\circ} \mathrm{C} \cdot \text { days }
$$

Then the required reduced total thermal resistance $\mathrm{R}_{\text {req }}$ :

$$
\mathrm{R}_{\text {req }}=3.079 \mathrm{~m}^{2 \circ} \mathrm{C} / \mathrm{W}
$$

3) The normative heat protection. We use the maximum value of reduced total thermal resistance $3.079 \mathrm{~m}^{2} \cdot{ }^{\circ} \mathrm{C} / \mathrm{W}$.

4) The area of humidity - humid $[18,19]$, we choice the thermotechnical characteristics of materials of cladding structures under conditions B [2]. We should calculate the thermal resistance for each layer of wall construction using formula:

$$
R=\frac{\delta}{\lambda}
$$

The first layer (concrete D400): $\mathrm{R}_{1}=2 \mathrm{~m}^{2} \cdot{ }^{\circ} \mathrm{C} / \mathrm{W}$.

The third layer (sand-cement rendering): $\mathrm{R}_{3}=0.00753 \mathrm{~m}^{2} \cdot{ }^{\circ} \mathrm{C} / \mathrm{W}$.

The evaluation of minimal required thermal resistance of insulation [4]:

$$
R_{\text {ins }}^{\text {req }}=R_{\text {req } 0}-\left(R_{\text {int }}+R_{\text {ext }}+\sum R_{i}\right)=0.913 \mathrm{~m}^{2} \cdot{ }^{\circ} \mathrm{C} / \mathrm{W}
$$

where: $R_{\text {int }}=1 / \alpha_{\text {int }}-$ inner surface heat exchange resistance;

$R_{\text {ext }}=1 / \alpha_{\text {ext }}$ - outer surface heat exchange resistance, $\alpha_{\text {ext }}-$ outside film coefficient of cladding structures under conditions of the cold period, $\alpha_{\mathrm{ext}}=23 \mathrm{~W} /\left(\mathrm{m}^{2 \circ} \mathrm{C}\right)[$ table 8,4$]$

$\Sigma \mathrm{R}=2.00753 \mathrm{~m}^{2} \cdot{ }^{\circ} \mathrm{C} / \mathrm{W}-$ sum of all resistances of wall layers without insulation, $\mathrm{m}^{2} \cdot{ }^{\circ} \mathrm{C} / \mathrm{W}$

5) The thickness of insulation: $\delta_{\text {ins }}=R_{\text {ins }}^{r e q} * \lambda_{\text {ins }}=0.029 \mathrm{~m}$. We take the thickness of layer $40 \mathrm{~mm}$.

where $\lambda_{\text {ins }}$ - coefficient of heat conductivity of insulation, $\mathrm{W} /\left(\mathrm{m} \cdot{ }^{\circ} \mathrm{C}\right)$.

6) The calculating of the thermal resistance of wall:

$$
R_{0}=\left(R_{\text {int }}+R_{\text {ext }}+\sum R_{\mathrm{T}, i}\right)=3.416 \mathrm{~m}^{2} \cdot{ }^{\circ} \mathrm{C} / \mathrm{W}
$$

where $\sum R_{\mathrm{T}, i}$ - sum of all resistances of wall layers, $\mathrm{m}^{2} \cdot{ }^{\circ} \mathrm{C} / \mathrm{W}$.

$$
\mathrm{R}_{0}=3.416 \mathrm{~m}^{2} \cdot{ }^{\circ} \mathrm{C} / \mathrm{W} \geq \mathrm{R}_{\mathrm{req}}=3.079 \mathrm{~m}^{2} \cdot{ }^{\circ} \mathrm{C} / \mathrm{W}
$$

\section{Results and Discussion}

The value of reduced total thermal resistance is bigger than the value of required resistance.

That is why this enclosing structure meets the heat transmission requirements [20].

The thickness of insulation is sizable for this wall construction.

The results of analogical calculations for the second construction are in table 3 . 
Table 3. Characteristics of wall constructions no.1, no.2.

\begin{tabular}{|c|c|c|c|}
\hline $\begin{array}{c}\text { The composition of the } \\
\text { walls from the inside out }\end{array}$ & $\begin{array}{c}\text { The thickness } \\
\text { of wall, } \mathrm{m}\end{array}$ & $\begin{array}{c}\text { The thickness of layer } \\
\text { "PENOPLEX WALL" } \\
\delta, \mathrm{m}\end{array}$ & $\begin{array}{c}\text { Thermal resistance of } \\
\text { wall, } \mathrm{m}^{2} \cdot{ }^{\circ} \mathrm{C} / \mathrm{W}\end{array}$ \\
\hline Construction no. & 0.347 & 0.04 & 3.416 \\
\hline Construction no.2 & 0.467 & 0.08 & 3.389 \\
\hline
\end{tabular}

\section{Conclusion}

The calculations showed that the wall construction composed of concrete, insulation and cement-sand plaster has smaller thickness of the insulating layer and lower total wall thickness and greater thermal resistance than the wall construction of the hollow brick, insulation and cement-sand plaster. In this case, it is recommended to use the first option while the design of the building in Saint-Petersburg.

\section{References}

1. URL: http://www.penoplex.ru/

2. Russian Building code 23-02-2003 "Thermal protection of buildings"

3. Russian Building code 23-01-99 "Construction climatology"

4. E.G. Malyavina, Waste heat (Abok, Moscow, 2007)

5. Russian Code of conduct 23-101-2004 "Design of thermal protection of buildings"

6. V.N. Kupriyanov, The design of thermal insulation of enclosing structures (KGASU, Kazan, 2011)

7. A.V. Rechinskiy, N.I. Vatin, O.S. Gamayunova, K.Y. Usanova, Construction of Unique Buildings and Structures, 2, 6-17 (2012)

8. O.S. Gamayunova, V.V. Ershov, A.A. Iljin, S.I. Li, B.V. Sokolov, Construction of Unique Buildings and Structures, 5, 26-30 (2012)

9. D.G. Arseniev, A.V. Rechinskiy, N.I. Vatin, O.S. Gamayunova, Construction of Unique Buildings and Structures, 2 (17), 5-24 (2014)

10. N.I. Vatin, O.S. Gamayunova, D. Petrosova, AMM, 635-637, 2085-2089 (2014)

11. N.I. Vatin, O.S. Gamayunova, D. Nemova, AMM, 638-640, 2460-2464 (2014)

12. D.G. Arseniev, A.V. Rechinskiy, K.V. Shvetsov, N.I. Vatin, O.S. Gamayunova, AMM, 635-637, 2076-2080 (2014)

13. O.S. Gamayunova, N.I. Vatin, Advanced Materials Research, 1065-1069, 2459-2462 (2015)

14. O.S. Gamayunova, K.Y. Usanova, Construction of Unique Buildings and Structures, 7(12), 10-19 (2013)

15. D.G. Arseniev, A.V. Rechinskiy, K.V. Shvetsov, N.I. Vatin, O.S. Gamayunova, Construction of Unique Buildings and Structures, 8 (23), 21-35 (2014)

16. N.I. Vatin, O.S. Gamayunova, Advanced Materials Research, 1065-1069, 2622-2625 (2015)

17. E.I. Gumerova, O.S. Gamayunova, Sofiia Pospelova, MATEC, 53, 01021 (2016) 
18. E.I. Gumerova, O.S. Gamayunova, Construction of Unique Buildings and Structures, 7 (46), 7-16 (2016)

19. O.S. Gamayunova, E.I. Gumerova, Procedia Engineering, 165, 1637-1642 (2016)

20. N.I. Vatin, A.S. Gorshkov, D.V. Nemova, Construction of Unique Buildings and Structures, 3 (8), 1-11 (2013) 